\title{
Occurrence of bovine tuberculosis at Nyala abattoirs in South Darfur State, Sudan
}

\author{
M.A. Aljameel ${ }^{1 *}$ M.B. Abdel Wahab ${ }^{2}$ A.O. Fayza ${ }^{2}$ \\ A.E. El Tigani ${ }^{3}$ M.M. Abdellatif ${ }^{4}$
}

\section{Keywords}

Cattle - Mycobacterium tuberculosis infection - Slaughterhouse - Sudan.

\begin{abstract}
Summary
The aim of this study was to determine the occurrence of tuberculosis in cattle slaughtered at Nyala abattoirs, South Darfur State, Sudan during the period April 2006 - May 2008. In total 2794 cattle were examined for tuberculous lesions. Tuberculous lesions $(n=163)$ were found in $40(1.4 \%)$ animals, among which seven had generalized tuberculosis and 33 localized tuberculosis, mainly in the lungs, thoracic lymph nodes, and/or in the liver, spleen, kidneys and mesenteric lymph nodes. Tissue samples were collected either in $10 \%$ formal saline for routine histopathology or in ice packs for direct microscopy and culturing. Direct microscopy showed that 124 (76.1\%) tuberculous lesions harbored acid fast bacilli, whereas 17 (10.4\%) isolates of Mycobacterium spp. were recovered in pure Lowenstein-Jensen medium cultures and identified as $M$. bovis $(n=11)$ and $M$. farcinogenes $(n=6)$. Granulomatous inflammation was evident in all sections of tuberculous lesions. Further studies are needed to identify mycobacteria species causing tuberculosis in other animal species.
\end{abstract}

\section{INTRODUCTION}

Bovine tuberculosis (BTB) is a chronic zoonotic bacterial disease characterized by progressive development of specific granulomatous tubercles in affected tissues and organs, more significantly in bronchial, mediastinal, retropharyngeal and portal lymph nodes. In addition, the lungs, liver, spleen and surface of body cavities are commonly affected $(13,15)$. Bovine tuberculosis is caused by slow growing non-photochromogenic members of the Mycobacterium

\footnotetext{
1. Department of Pathology, Nyala Veterinary Research Laboratory, Nyala, Sudan 2. Department of Microbiology, Veterinary Research Institute, Khartoum, Sudan.

3. Department of Veterinary Medicine, Faculty of Agriculture \& Veterinary Medicine, Qassim University, Saudi Arabia.

4. Department of Microbiology, Faculty of Science, North Border University, Saudi Arabia.

* Corresponding author

Tel: +249912693622

E-mail: aljameel79@hotmail.com
}

tuberculosis complex: M. bovis, $M$. caprae, M. microti, $M$. africanum, M. canettii and $M$. pinnipedii. However, M. bovis is the most universal pathogen among mycobacteria and affects many domestic and wild animals. Cattle, goats and pigs are most susceptible, whereas sheep and horses have a high natural resistance $(19,24)$. Bovine tuberculosis is widely distributed throughout the world and causes serious economic losses in animal production (6). In cattle, inhalation of $M$. bovis is considered to be the most frequent route of infection but ingestion of contaminated material can also cause infection (3). Tuberculous lesions usually have a yellowish appearance and are caseous, caseo-calcareous, or calcified in consistency. A tubercle is described as a granulomatous lesion, characteristically composed of a caseous or necrotic center bordered by a zone of epithelioid cells, some of which may form multinucleated giant cells, accumulation of lymphocytes, a few granulocytes, and encapsulation of fibrous connective tissue of varying thickness $(20,25,16)$. Tuberculosis is detected in live cattle by tuberculin test, in addition to other tests such as the cellular test based on the quantification of gamma interferon. At postmortem examination it 
is diagnosed and confirmed by bacteriological, histopathological and molecular methods $(7,9,10,14,17)$.

In Sudan, studies conducted in the 1960's and 1970's indicated that the incidence was high in the humid southern part of the country where the animals are in close contact, and low in the dry zones where the nomadic cattle of Western provinces, the seminomadic cattle of Eastern and Central Sudan are reared $(11,23)$. Sulieman and Hamid (22) found that $64(53.3 \%)$ of 120 caseous lesions from cattle in Eastern and Central Sudan were due to acid-fast bacilli (AFB), whereas $56(46.7 \%)$ were due to other causes. Growth on Lowenstein-Jensen slants was obtained in 52 of the 120 samples and identified as follows: 25 (48.1\%) Mycobacterium bovis, 21 (40.4\%) M. farcinogenes, 4 (7.7\%) M. tuberculosis, 1 (1. 9\%) M. avium, and 1 (1.9\%) Nocardia sp.

In South Darfur State, El Tigani-Asil et al. (8) report a bovine tuberculosis prevalence of $0.18 \%$ in slaughtered cattle. The true epidemiological picture of the disease in different parts of Sudan is still unclear. Determination of the prevalence of the disease in various regions of the country will help establish control and prevention policies. This study aimed to detect bovine tuberculosis and identify the causative agents among cattle slaughtered at Nyala abattoirs.

\section{MATERIALS AND METHODS}

The study was conducted in Nyala abattoirs, South Darfur State, Sudan, from April 2006 to May 2008. Cattle $(\mathrm{n}=2794)$ slaughtered at Nyala abattoirs were examined by visual and physical inspection of external and internal organs, with special consideration to systemic portal lymph nodes for presence of caseous nodules. Tuberculous tissue samples $(n=163)$ were collected from infected animals $(n=40)$ either in $10 \%$ neutral buffered formalin for routine histopathology or in sterile plastic containers which were kept in ice packs and carried to Nyala Veterinary Research Laboratory within two hours for direct microscopy and culturing. Ten percent neutral formal saline fixed tissues were processed and embedded in paraffin wax; $5 \mu$ m-thick sections were stained with hematoxylin and eosin for histopathological examination (2). Direct smears were prepared from caseous tissue material and Ziehl-Neelsen stained for acid fast bacilli (18).

A portion of each sample was homogenized with $5 \mathrm{ml}$ of sterile normal saline using a sterile mortar and pestle. Then $2 \mathrm{ml}$ of the homogenate was transferred into sterile centrifuge tubes, decontaminated by adding an equal volume of sterile $4 \% \mathrm{NaOH}$ ( $2 \mathrm{ml}$ ) for $10 \mathrm{~min}$, and centrifuged at $3000 \mathrm{rpm}$ for $15 \mathrm{~min}$. After centrifugation, to recover sediment, the supernatant was rejected and the sediment neutralized with $1 \% \mathrm{HCl}$, with phenol red as indicator. Neutralization was achieved when the color of the solution changed from purple to yellow (5). The sediment from some samples was inoculated onto a set of Lowenstein-Jensen (LJ) medium slants supplemented with $4 \%$ sodium pyruvate (LJ pyruvate) and the rest was enriched with glycerol (standard LJ). Cultures were incubated at $37^{\circ} \mathrm{C}$ for up to 12 weeks. Mycobacteria growth was evidenced by phenotypic characteristics of pure visible colonies and confirmed by Ziehl-Neelsen stained films from the cultures (18).

Identification of $M$. tuberculosis complex was carried out according to growth rate, colony morphology, niacin production, pyrazinamide deamination, nitrate reduction, urease production, 5\% $\mathrm{NaCl}$ tolerance, inhibition by thiophen-2-carbonic acid hydrazide (TCH) $10 \mathrm{mg} / \mathrm{ml}$, and catalase activity and its thermolability to $68^{\circ} \mathrm{C}(18,12)$.

\section{- RESULTS}

Yellowish caseous necrotic lesions of various sizes enclosed in hard white to light grey fibrous tissue (Figure 1) were observed in infected carcasses $(n=40)$. Seven $(17.5 \%)$ had generalized tuberculosis, whereas $33(82.5 \%)$ had localized tuberculosis mainly in the lungs and thoracic lymph nodes, and/or liver, spleen and mesenteric lymph nodes.

Gross examination revealed typical tuberculosis lesions with caseous or mineral material in various organs (Figure 1). Histopathology revealed necrotic centers bordered by zones of epithelioid cells, accumulation of lymphocytes, granulocytes, some of which forming multinucleated giant cells. Lesions were encapsulated by fibrous tissue of varying thickness (Figure 2). In some sections there were central necrotic areas with some mineralization surrounded by epithelioid cells and lymphocytes encapsulated by a thick zone of fibrous tissue (Figure 2). Microscopy evidenced that $124(76.1 \%)$ smears harbored acid fast bacteria, whereas 39 (23.9\%) were negative (Figure 2).

Seventeen (10.4\%) samples grew on pyruvate LJ medium during three-month incubation, whereas $146(89.6 \%)$ failed to grow or promoted contaminant growth (Table I). Eleven isolates (64.7\%) were identified as M. bovis and six (35.3) as M.farcinogenes.

Table I

Direct microscopy and isolation of Mycobacterium sp.

\begin{tabular}{|c|c|c|c|c|c|}
\hline \multirow[t]{2}{*}{ Organ/tissue } & \multirow[t]{2}{*}{ Number (\%) } & \multicolumn{2}{|c|}{ Direct microscopy } & \multicolumn{2}{|c|}{ Isolation } \\
\hline & & Positive (\%) & Negative (\%) & Positive (\%) & Negative (\%) \\
\hline Lungs & $30(18.4)$ & $24(80.0)$ & $6(20.0)$ & $7(23.3)$ & $23(76.7)$ \\
\hline Liver & $17(10.4)$ & $12(70.6)$ & $5(29.4)$ & $2(11.8)$ & $15(88.2)$ \\
\hline Spleen & $9(5.5)$ & $8(88.9)$ & $1(11.1)$ & $2(22.2)$ & $7(77.8)$ \\
\hline Kidneys & $5(3.0)$ & $3(60.0)$ & $2(40.0)$ & $1(20.0)$ & $4(80.0)$ \\
\hline Pleura & $6(3.7)$ & $4(66.7)$ & $2(33.3)$ & $0(0.0)$ & $6(100.0)$ \\
\hline Peritoneum & $4(2.5)$ & $3(75.0)$ & $1(25.0)$ & $0(0.0)$ & $4(100.0)$ \\
\hline Lymph nodes & $92(56.4)$ & $70(76.1)$ & $22(23.9)$ & $5(5.4)$ & 87 (94.6) \\
\hline Total & 163 & $124(76.1)$ & $39(23.9)$ & $17(10.4)$ & $146(89.6)$ \\
\hline
\end{tabular}



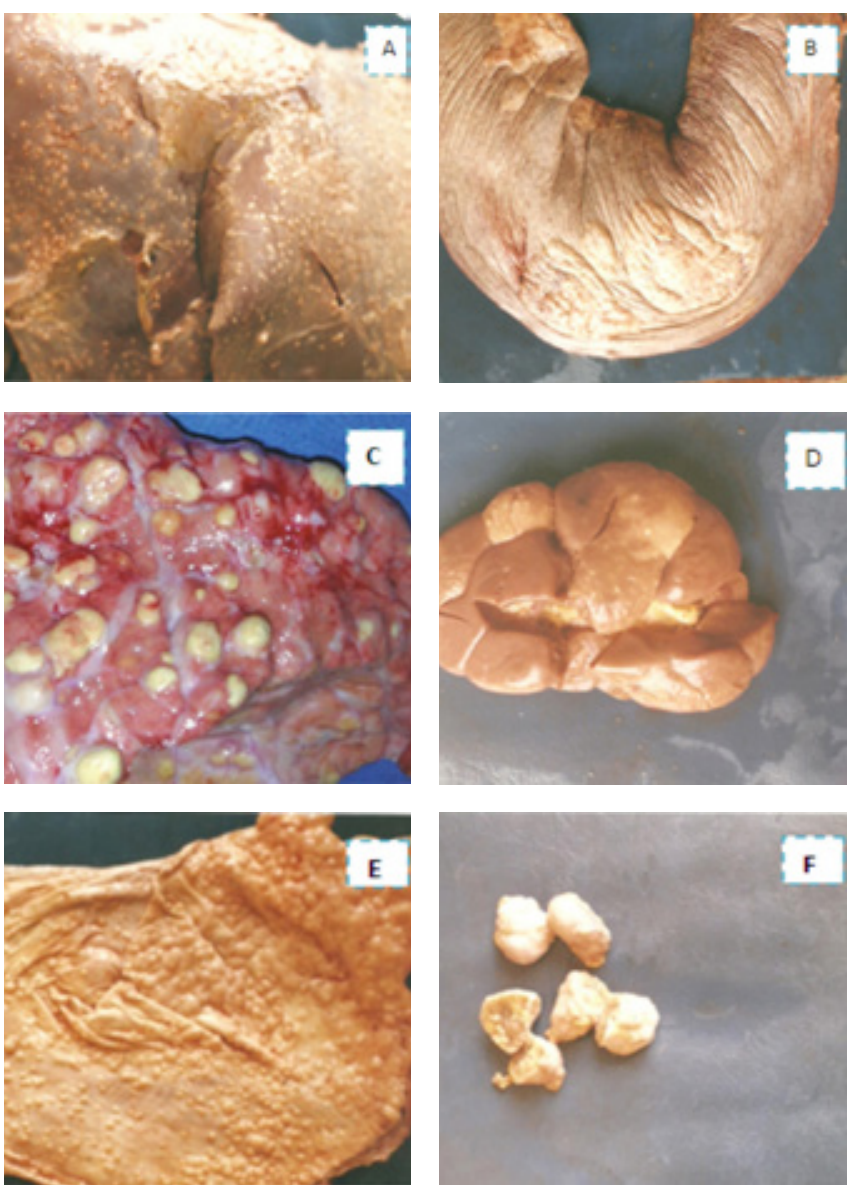

Figure 1: Liver $(A)$, spleen $(B)$, lung $(C)$, kidney $(D)$, peritoneum $(E)$ and bronchial lymph node $(F)$ showing tubercles with caseous necrotic areas and calcifications.

\section{DISCUSSION}

Eradication programs and control of BTB based on test and slaughter of tuberculin positive reactors have been adopted in some countries. Application of these programs in developed countries has eradicated or drastically reduced the infection rate in farm animals (1). In Sudan, especially in South Darfur, control of the disease through the test-and-slaughter policy has not been adopted yet because of the lack of knowledge on the actual prevalence of the disease, the absence of cattle identification and control of animal movements, and prevailing technical and financial limitations. The control of bovine tuberculosis is only based on the detection of gross lesions in abattoirs and subsequently partial or total condemnation of carcasses. The incidence of tuberculosis in this study was low compared to previous reports (22), and high to some extent compared to results obtained by El Tigani-Asil et al. (8). BTB prevalence might be underestimated in tuberculous cattle because of undetected lesions in early infection or because small lesions might be missed as a result of difficulties in carrying out inspection without pressure.

In the 40 carcasses with tuberculous lesions, localized tuberculosis was higher than generalized tuberculosis in the infected cattle which may indicate that cattle in the region were infected by aerosol and/or ingestion of contaminated material (3). Histopathological examinations of lesions showed typical granulomas characterized by central necrosis surrounded by multinucleated, Langhans, epithelioid and lymphocyte cells. This is consistent with findings by Whipple et al. (25) who observed typical granulomatous lesions
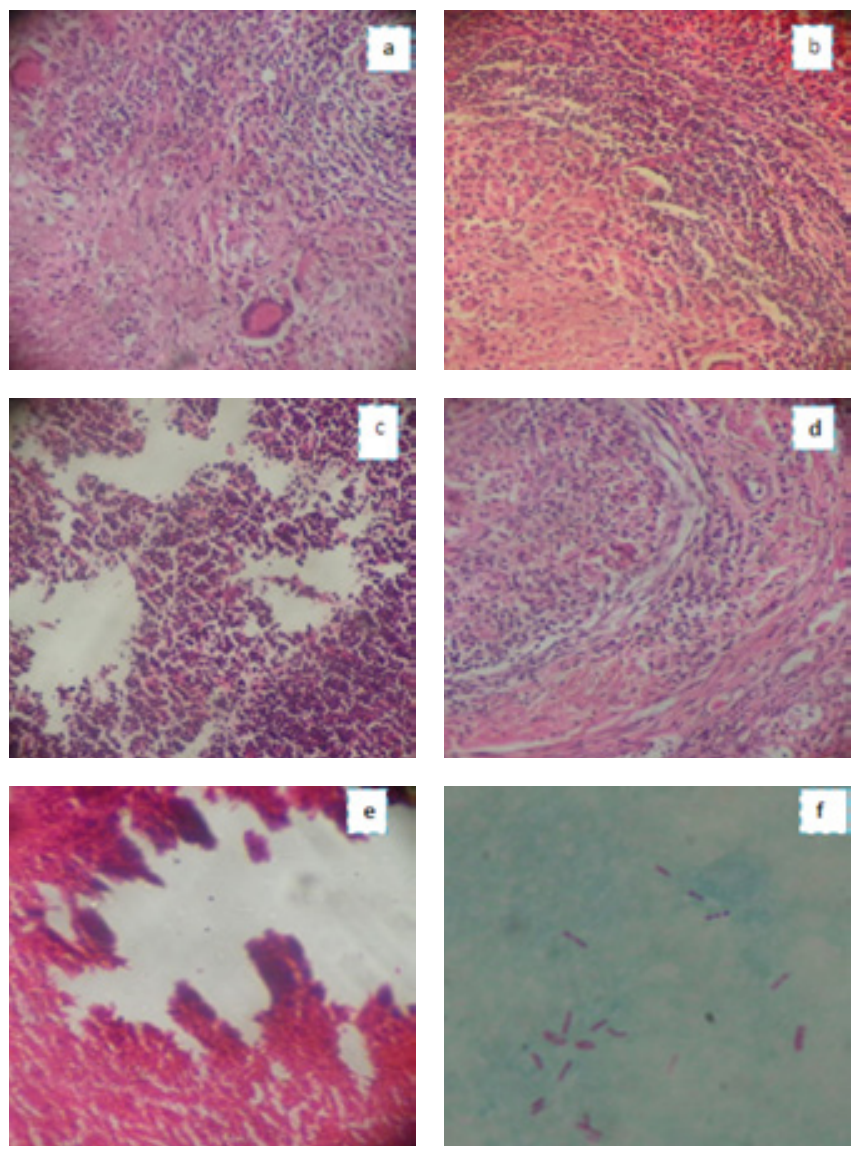

Figure 2: Lung (a), spleen (b), bronchial lymph node (c), and kidney $(d)$ showing a necrotic center surrounded by epithelioid cells, lymphocytes, multinucleated giant cells (a and b); liver (e) showing a central necrotic areas with mineralization surrounded by fibrous connective tissues. Hematoxylin and eosin stains (x 40 magnification). Ziehl-Neelsen's stained film (f) showing acid fast bacilli (100 x oil immersion objective).

in tissues with evident gross lesions. These granulomas were characterized by a central necrotic area and focal mineralization (20). Microscopic examination evidenced a high number of AFB (76.1\%) and confirmed that microscopy is essential to establish BTB diagnosis especially in developing countries, echoing OIE which states that microscopic examination provides presumptive confirmation (15). Our finding is not consistent with that of Sahraoui et al. (21) who only found $28.85 \%$ positive smears.

In the present study $(\mathrm{n}=163)$ a low culture positive rate $(10.4 \%)$ was recorded. Sahraoui et al. (21) reported $51.6 \%$ positive cultures. It might be caused by the absence of viable mycobacteria in calcified lesions or the toxic adverse effect of decontaminants which kill the organism during long incubation periods. It has been established that in completely calcified lesions, tuberculous bacilli are usually dead and do not grow on LJ media (18). Furthermore, mycobacteria cannot be isolated from healed lesions (4). The isolation of mycobacteria on selective culture media and their subsequent identification by cultural and biochemical tests or DNA techniques such as PCR are needed to confirm the infection in different animal species.

\section{CONCLUSION}

To the best of our knowledge, tuberculosis research in Sudan, especially in conflict areas, is scarce. It is however essential to 
improve animal health, increase productivity and control this zoonotic disease. Furthermore, comparative tuberculosis studies are also crucial to map the disease and define national or international control policies.

\section{Acknowledgments}

The authors wish to thank the staff of the Department of Pathology at the Veterinary Research Institute for their assistance. The permission of the Director General of the Animal Resources Research Corporation to publish this article is acknowledged.

\section{REFERENCES}

1. AYELE W.Y., NEILL S.D., ZINSSTAG J., PAVLIK I., 2004. Bovine tuberculosis: an old disease but a new threat to Africa. Int. J. Tuber. Lung. Dis., 8: 924-937.

2. BANCROFT D.J., COOK C.H., STRILING R.W., TURNER D.R., 1994 Manual of histological techniques and their diagnostic application. Edinburgh, UK, Churchill Livingstone, p. 15-118.

3. BIET F., BOSCHIROLI M.L., THOREL M.F., GUILLOTEAU L.A., 2005 Zoonotic aspects of Mycobacterium bovis and Mycobacteriumaviumintracellulare complex (MAC). Vet. Res., 36: 411-436.

4. BUSH M., MONTALI R.J., PHILLIPS L.G., HOLOBAUGH P.A., 1990 Bovine tuberculosis in a Bactrian camel herd: Clinical therapeutic, and pathologic findings. J. Zoo. Wildl. Med., 21: 171-179.

5. CORNER L.A., 1994. Postmortem diagnosis of Mycobacterium bovis infection in cattle. Vet. Microbiol., 40: 53-63.

6. COSIVI O., GRANGE J.M., DABRON C.J., RAVIGLIONE M.C., FUJIKURA T., COUSINS D., ROBINSON R.A., HUCHZERMEYER H.F., DE KANTOR I., MESLIN F.X., 1998. Zoonotic tuberculosis due to Mycobacterium bovis in developing countries. Emerg. Infect. Dis., 4 $1-17$.

7. COUSINS D.V., FRANCIS B.R., GOW B.L., 1989. Advantages of a new agar medium in the primary isolation of Mycobacterium bovis. Vet. Microbiol., 20: 89-95.

8. ELTIGANI-ASIL A.A., ELSANOSI S.A., GAMEEL A., HAYTHAM E., FATHELRAHMAN H., TERAB N.M., MUAZ M.A., HAMID M.E., 2013 Bovine tuberculosis in South Darfur State, Sudan: an abattoir study based on microscopy and molecular detection methods. Trop. Anim. Health Prod., 45: 469-472.

9. HUARD R.C., DE OLIVEIRA LAZZARINI L.C., BUTLER W.R., VAN SOOLINGEN D., JOHL HO., 2003. PCR-based methods to differentiate the subspecies of Mycobacterium tuberculosis complex on the basis of genomic deletions. J. Clin. Microbiol., 41: 1637-1650.

10. KAMERBEEK J., SCHOULS L., KOLK A., VAN SOOLINGEN D., VAN AGTERVELDM., KUIIPER S., BUNSCHOTEN A., MOLHUIZEN H., SHAW R., GOYAL M., VAN EMBDEN J., 1997. Simultaneous detection and strain differentiation of Mycobacterium tuberculosis for diagnosis and epidemiology. J. Clin. Microbiol., 35: 907-914.
11. KARIB A.A., 1962. Bovine tuberculosis in Sudan. Sudan. J. Vet. Sci. Anim. Husb., 3: 1-8.

12. KONEMANN E.W., ALLEN S.D., JANDA W.M., 2005. Mycobacteria. In: Winn W.C. et al., Eds, Koneman's Color atlas and textbook of diagnostic microbiology, 6th Edn. Philadelphia, PA, USA, Lippincott William \& Wilkins, p. 1496-1514.

13. NEILL S.D., POLLOCK J.M., BRYSON D.B., HANNA J., 1994. Pathogenesis of Mycobacterium bovis infection in cattle. Vet. Microbiol., 40: $41-52$.

14. NIEMANN S., HARMSEN D., RUSCH-GERDES S., RICHTER E., 2000. Differentiation of clinical Mycobacterium tuberculosis complex isolates by gyrB DNA sequence polymorphism analysis. J. Clin. Microbiol., 38: 3231-3234.

15. OIE, 2009. Bovine tuberculosis. OIE Terrestrial Manual. Paris, France, OIE, p. 1-16.

16. PALMER M.V., WATERS W.R., THACKER T.C., 2007. Lesion development and immunohistochemical changes in granulomas from cattle experimentally infected with Mycobacterium bovis. Vet. Pathol., 44: 863-874.

17. PARSONS L.M., BROSCH R., COLE S.T., SOMOSKOVI A., LODER A., BRETZEL G., VAN SOOLINGEN D., HALE Y.M., SALFINGER M., 2002. Rapid and simple approach for identification of Mycobacterium tuberculosis complex isolated by PCR-based genomic deletion analysis. J. Clin. Microbiol., 40: 2339-2345.

18. QUINN P.J., CARTER M., DONNELLY C.J., LEONARD C.F., 2002. Veterinary microbiology and microbial diseases, 1st Edn. London, UK, Blackwell Science, p. 113-118.

19. RADOSTITS O.M., GAY C.C., BLOOD D.C., HINCHELIFT K.W., 2000. Disease caused by Mycobacterium. In: Veterinary medicine: A textbook of disease of cattle, sheep, pig, goat and horses, 9th Edn. London, UK, Harcourt Publisher, p. 909-918.

20. RHYAN J.C., SAARI D.A., 1995. A comparative study of the histopathologic features of bovine tuberculosis in cattle, fallow deer (Dama dama), Sika deer (Cervus nippon) and red deer (Cervus elaphus) and elk. Vet. Pathol., 32: 215-220.

21. SAHRAOUI N., MULLER B., YALA D., OUZROUT R., ZINSSTAG J., BOULHBAL F., GUETAMI D., 2008. Investigation about the bovine tuberculosis in two Algerian slaughterhouses. Afr. J. Agric. Res., 3: 775778.

22. SULIEMAN M.S., HAMID M.E., 2002. Identification of acid fast bacteria from caseous lesions in cattle in Sudan. J. Vet. Med. B., 49: 415418.

23. TAGELDIN M.H.A., 1971. Comparative study of pathology and bacteriology of human and animal tuberculosis in Sudan. Doct. thesis, University of Khartoum, Sudan, $87 \mathrm{p}$.

24. THOEN C.O., STEELE J.H., GILSDORF M.J., 2006. Mycobacterium bovis infection in animals and humans, 2nd Edn. Ames, IA, USA, Blackwell Professional, $317 \mathrm{p}$.

25. WHIPPLE D.L., BOLIN C.A., MILLER J.M., 1996. Distribution of lesions in cattle infected with Mycobacterium bovis. J. Vet. Diagn. Investig., 8: 351-354.

Accepted 29 January 2015; Online publication March 2015 


\section{Résumé}

Aljameel M.A., Abdel Wahab M.B., Fayza A.O., El Tigani A.E., Abdellatif M.M. Incidence de la tuberculose bovine dans les abattoirs de Nyala dans I'Etat du Darfour du Sud au Soudan

L'objectif de l'étude a été de déterminer l'incidence de la tuberculose chez les bovins abattus dans les abattoirs de Nyala, Etat du Darfour du Sud au Soudan, pendant la période d'avril 2006 à mai 2008. Au total, 2794 bovins ont été examinés pour la présence de lésions tuberculeuses. Ces dernières ( $\mathrm{n}=163)$ ont été retrouvées dans 40 (1,4 p. 100) animaux, sept ayant présenté une tuberculose généralisée et 33 une tuberculose localisée, principalement dans les poumons, les ganglions lymphatiques thoraciques, et/ou dans le foie, la rate, les reins et les ganglions lymphatiques mésentériques. Des échantillons tissulaires ont été placés soit dans une solution de formol à 10 p. 100 pour un examen histopathologique de routine, soit dans de la glace pour un examen en microscopie directe et une mise en culture. La microscopie directe a montré que 124 (76,1 p. 100) lésions tuberculeuses contenaient des bacilles acido-alcoolo-résistants, tandis que 17 (10,4 p. 100) isolats de Mycobacterium spp. ont pu être cultivés en milieu de culture de Löwenstein-Jensen pur et identifiés comme étant $M$. bovis $(n=11)$ et $M$. farcinogenes $(n=6)$. Une inflammation granulomateuse a été observée dans toutes les coupes de lésions tuberculeuses. D'autres études seront nécessaires pour identifier les espèces de mycobactéries responsables de la tuberculose chez d'autres espèces animales.

Mots-clés : Bovin - Infection Mycobacterium tuberculosis Abattoirs - Soudan.

\section{Resumen}

Aljameel M.A., Abdel Wahab M.B., Fayza A.O., El Tigani A.E., Abdellatif M.M. Ocurrencia de tuberculosis bovina en ganado de sacrificado en mataderos Nyala en el Estado de Darfur del Sur, Sudan

El estudio se llevó a cabo con el fin de detectar tuberculosis en ganado sacrificado en los mataderos de Nyala, estado de Darfur del Sur, Sudan, durante el periodo entre abril 2006 y mayo 2008. Un total de 2794 cabezas fueron inspeccionadas para la observación de lesiones tuberculosas. Las lesiones tuberculosas $(n=163)$ se encontraron en $40(1.4 \%)$ animales, siete con tuberculosis generalizada y 33 con tuberculosis localizada, principalmente en el pulmón y los linfonodos torácicos y/o hígado, baso, riñones y linfonoos mesentéricos. Se colectaron muestras de tejido, sea en $10 \%$ formol salina para histopatología de rutina o en paquetes de hielo para microscopia directa y cultivo. La microscopia directa mostró que $124(76,1 \%)$ de las lesiones tuberculosas albergaron bacilos ácidos-alcohol resistentes, mientras que 17 (10,4\%) Mycobacterium spp. fueron aislados en cultivos en medio de Lowenstein-Jensen puro e identificados como $M$. bovis y $M$. farcinogenes $(\mathrm{n}=6)$. Inflamación granulomatosa fue evidente en todas las secciones de las lesiones tuberculosas. Más estudios son necesarios para identificar las especies de micobacterias causantes de tuberculosis en otras especies.

Palabras clave: Ganado bovino - Infección Mycobacterium tuberculosis - Matadero - Sudán. 
